\title{
Role of Ethical Marketing in Driving Consumer Brand Relationships and Brand Loyalty: A Sustainable Marketing Approach
}

\author{
Muhammad Tanveer ${ }^{1, *}$, Abdul-Rahim Ahmad ${ }^{2}$, Haider Mahmood $^{3} \mathbb{D}$ and Ikram Ul Haq ${ }^{4}(\mathbb{D}$ \\ 1 Prince Sultan University, Riyadh 11586, Saudi Arabia \\ 2 KFUPM Business School, Dhahran 31261, Saudi Arabia; abdulrahim.ahmad@kfupm.edu.sa \\ 3 Department of Finance, College of Business Administration, Prince Sattam bin Abdulaziz University, \\ Alkharj 11942, Saudi Arabia; h.farooqi@psau.edu.sa \\ 4 King Abdullah International Medical Research Center, College of Dentistry, \\ King Saud bin Abdulaziz University for Health Sciences, Riyadh 11481, Saudi Arabia; \\ ikram34439@yahoo.com \\ * Correspondence: mtanveer@psu.edu.sa
}

Citation: Tanveer, M.; Ahmad, A.-R.; Mahmood, H.; Haq, I.U. Role of Ethical Marketing in Driving Consumer Brand Relationships and Brand Loyalty: A Sustainable Marketing Approach. Sustainability 2021, 13, 6839. https://doi.org/ $10.3390 /$ su13126839

Academic Editor: Shervin Hashemi

Received: 6 June 2021

Accepted: 12 June 2021

Published: 17 June 2021

Publisher's Note: MDPI stays neutral with regard to jurisdictional claims in published maps and institutional affiliations.

Copyright: (c) 2021 by the authors. Licensee MDPI, Basel, Switzerland. This article is an open access article distributed under the terms and conditions of the Creative Commons Attribution (CC BY) license (https:// creativecommons.org/licenses/by/ $4.0 /)$.

\begin{abstract}
This research is focused on studying the impact of ethical marketing practices on valueadding product sustainability and customer brand relationship sustainability. It further investigates the consequent effects of value-adding product sustainability and customer brand relationship sustainability on brand loyalty. Data for this study were collected from a sample of 1500 customers having multiple interactions with goods and brands of retail organizations in Pakistan. We employed structural equation modeling (SEM) using SPSS 24.0 to analyze our data. The findings of this paper provide empirical support to the proposed relationships. More specifically, ethical marketing practices were found to have a significant impact on value-adding product sustainability and customervalue brand relationship sustainability. The findings also support a positive impacts of valueadding product sustainability and customer-value brand relationship sustainability on brand loyalty. This study provides some valuable implications for the theory and practice in that it identifies and empirically validates key ethical marketing factors affecting loyalty in business-to-consumer interactions. Besides, this study advocates implications for firms regarding some key aspects of ethical marketing practices that should be strengthened to achieve sustained brand loyalty.
\end{abstract}

Keywords: ethical marketing; extended marketing mix; consumer brand relationships; brand loyalty; sustainability

\section{Introduction}

Building strong customer relationships and loyalty is increasingly important for companies in today's rapidly changing marketing environment [1,2]. Developing sustained brand loyalty has attained such a staggering attention because it helps firms in developing advantages that are viable in the markets [3]. It has been observed that the attainment of brand loyalty is based on programs related to the corporate marketing [4-7]. Typically, brand loyalty is reflected in how customers evaluate the company's outlook towards the product evaluation and consumer-brand relations [8-10]. Certain studies have argued that companies should give their brand message while considering social and environmental problems, and sell their products to consumers [11,12]. Strategies focused on common issues increase the interest of consumers in buying the products or services from such companies. Given that modern societies require companies to be responsible and ethical to their stakeholders. Therefore, the maintenance of consumer relationships and brand loyalty are not easy to attain and pose major challenges to firms in today's marketing environment.

Ethical marketing strategies have been studied for nearly all business areas which are formulated to gain a competitive advantage [13-17]. A company's ethical marketing 
practices affect the daily routine of consumer activity. Every company's ethical marketing practices are closely related to the purchase of products or services, regardless of whether it is conscious of consumer purchasing power strengths and weaknesses. The importance of ethics in the advancement of business sustainability, and general marketing issues (including product safety, price tags and advertising) has duly been recognized by corporate managers and vendors [18]. As an outcome, an economic behavior, whether ethical or non-ethical, is inherently linked with a company's overall reputation and assessment, and stresses the fundamental factors in keeping the company competitive on the market [19-21].

Despite the apparent significant role of ethical marketing practices on relationship building, product evaluation, and high-brand loyalty, only a few studies have examined the effects of extended marketing mix elements (viz. product, price, place, promotion, person, physical evidence, and packaging) on consumption and brand loyalty [22-26]. Moreover, ethical marketing practice plays a significant role in improving consumer-firm ties, product assessment, and brand loyalty [27-29]. Only a few studies have examined the role of ethical marketing mix elements on such attitudinal and behavioral outcomes [18,30,31]. Moreover, the literature has explored the effects of extended marketing mix elements on value-adding product sustainability and customer-brand relationship sustainability in B2C transactions from an ethical marketing perspective [32,33]. Nevertheless, the focus of the literature was on the 4Ps of the marketing mix in this regard. Hence, the present study highlighted this literature gap and contributed by exploring the role of extended marketing mix with the 7Ps approach from an ethical marketing perspective. The findings of this study would be attractive for the companies to build an ethically rich culture, adopting the proposed extended marketing mix with the 7Ps approach that offers fair and trustoriented transactions. Such an ethically sound approach can help companies facilitate strong relationship building and brand loyalty, which eventually offers them a competitive advantage to survive and sustain for the long term.

\section{Theoretical Background}

\subsection{Ethical Marketing}

In the literature, "ethics" describes concepts like good and evil, correct and false, virtue and sin, justice and crime [33-36]. Ethics seeks to address the human moral issues. The fields of moral psychology, descriptive ethics, as well as value theory are all connected to ethical philosophy [37]. The words "ethics" or "morals" in the literature refer to a collection of moral standards [38], values and beliefs and moral principles, such as moral decisions, standards, norms and laws, and the essence and motivations that direct people to behave a certain way [39-44]. Gaski [45] defined ethical marketing as "a code of morals and conduct used in marketing practices". Ethical marketing drives companies make marketing decisions that are morally acceptable in terms of ties between marketing managers and other stakeholders including customers, employees, competitors, and general public [39]. Ethical marketing is an important subject for both academia and practitioners because ethical principles require companies abide by the minimum standards of liability and conduct their marketing activities in ways that make business transparent and acceptable to all [46-51].

The significance of ethical marketing is further highlighted by the fact that consumers in modern societies continue to require high-quality products and prefer socially renowned brands even though they may aquire those products at higher prices [52]. Ethical marketing typically contributes to a more culturally sensitive and socially conscious business culture. Given that marketing is a big part of any business model, ethical marketing forms an integral part of corporate ethics [53-56]. Built on the theoretical underpinnings of ethical marketing, ethical practices should be applied while analyzing whether the product or the service is portrayed accurately and factually in terms of cultural and social values. Ethical marketing practices provide directions to managers and marketers on how to deal with an ethical issue [57]. Certain researchers consider the use of moral principles in marketing decisions a systematic approach. 
This study has considered practices encompassing ethics related to the extended marketing mix elements, viz. product, price, place, promotion, person, physical evidence, and packaging. Several scholars have highlighted the ethics approach of a marketing combination. Ethics related to product decisions offer a competitive advantage and determine if such products are detrimental to customers. The concept of proportion and justice is included in price-related ethics. Ethical pricing should be equivalent to the advantage gained from the product by the consumer [58]. Unreasonable pricing may influence the structure of competition. Ethics related to place-specific decisions emerge largely in relationships along distribution channels as some organizations sometimes follow ethical actions, including abuse of power $[59,60]$. Promotional ethics issues can be analyzed in marketing and personal sales. Promotional ethics covers questions of marketing, sales and public relations [61]. Other examples of person-specific ethical issues include difficulties with sales advertisements for customers by brokers and suppliers as well as conflicts with advertising media organizations. Physical evidence and packaging specific ethical approach are directed towards a more socially conscious way of thinking; wherein adjustments are made because of its concerns about the ethical issues such as child labor, working climate, ties with third-world countries and environmental problems [62-64].

Considering these arguments, this study intends to build a theoretical framework that explains the relationship of the above discussed extended marketing mix elements from an ethical perspective with some specific consumer behavioral outcomes, which we discuss in the following sections.

\subsection{Consumer-Value Brand Relationship Sustainability}

To illustrate the common elements of relationship sustainability (RS) which have evolved over the past few decades are relationship marketing and branding [65-67]. Therefore, it is important to analyze the recent branding context description for consumer product identification (CPI). The questions arising with respect to its nature and its connection to RS are equally important. The significance of the relationship between brand and customer are reflected by various terms viz. brand influence, brand identity, personal relationships, brand trust, brand interdependence, and brand loyalty. From a sustainable relationship perspective, if customers are happy, it leads to an increase in the potential of the brand in particular as well as the company in general $[68,69]$. Previous models of this relationship provide hierarchical aspects of the cognitive, affective and conative elements. This means that connections between customers and brands are formed and maintained over a period of time. The main factors influencing the quality of brand relations between customers include acquisition experience, emotional experience, experience in action, cognitive convictions, and brand commitment [70]. Prior research suggests that in order to enhance the consumer-brand relationship and strengthen the moral aspect and ethical relationships of a business with its consumers, factors specific to the quality of a consumer-brand connection need to be considered [71-74]. Consumer brand partnership sustainability is an alliance created through a mechanism in which customers and brands play their part and engage on a marketplace, as two equal parties. Relationship marketing theory further propounds that a product can longer win a customer's favor through just quality, rather customers often look for brands that focus on building an engaging and sustainable relationship with them.

\subsection{Brand Loyalty}

Scholars have investigated the concept of brand loyalty across contexts extensively over the past few decades $[75,76]$. The concept of loyalty is used in different situations and, therefore, varies across contextual dimensions. Different conceptualizations of brand loyalty have been offered by scholars over time. For instance, brand loyalty is "the probability that a consumer will purchase or recommend a particular product or service" [77,78]. Similarly, the 1999 Oliver in defined loyalty as "a deeply held commitment to re-buy or repatronize a preferred product or service consistently in the future, despite situational influences and marketing efforts having the potential to cause switching behavior" [79]. 
Furthermore, some scientists consider brand loyalty to be a strong commitment to disposing, contributing to customers avoiding situational pressures and marketing strategies that may help to brand change. The commitment to action is demonstrated by the customer's true buying conduct towards a certain brand. Products may have the potential to engage customers and to make them feel emotionally attached [80,81]. Customer beliefs and perceptions build brand images, and this has an effect on the way they view brands they come in contact with. Therefore, companies cannot just rely on informing customers about their products/services, rather they also have to provide exceptional customer experiences to make them sustainably loyal over a period of time [2]. This loyal base of customers will serve as a sustainable competitive advantage for companies across industries.

\subsection{Contribution of the Present Study}

The literature has signified the role of ethics in basic marketing principles [33-36]. Hence, marketing ethics should satisfy all business stakeholders [39]. Therefore, a majority of the literature has investigated the role of ethical marketing in satisfying the business stakeholders [46-51]. The literature has also integrated ethical marketing with overall corporate ethics [53-56]. Ethical marketing may win the customer's confidence, which would help develop a sustainable relationship between brand and customer [68-74]. A vast literature has investigated the role of ethical standards in extended marketing mix elements on brand loyalty [22-29], on the attitudinal and behavioral outcomes [30,31], and on the customer-brand relationship sustainability in B2C transactions [32,33]. However, the literature has investigated the ethical marketing in limited marketing mix elements. This present study extended the scope of empirical literature, focusing on the 7 Ps, i.e., product, price, place, promotion, person, physical evidence, and packaging, in the extended marketing mix to improve consumer brand relationship sustainability. The literature has floated the ethical marketing implications for a limited extended marketing mix. However, the present study provided more holistic view of the extended marketing mix in the theoretical debate of ethical marketing. Moreover, it also opens the doors for practitioners to adopt the greater dimensions of managerial and marketing tools to win the customer loyalty in the campaigns of their brands to accelerate the consumer brand relationships sustainability.

\section{Conceptual Model and Hypothesis Development}

Marketing mix strategy explains how a company offers services and products to satisfy the requirements of divisions of the target market [82]. Marketing strategy with ethical perspectives concern with the righteous behavior and high minded beliefs that enlighten the venture which is marketable so that marketing strategies are applicable for ethical deliberations. Problems in ethical marketing take place further continually in such zones where legitimate acts can be sometimes immoral or in which the lawfulness or morality of actions is undetermined [1]. In order to create positive effects on consumers and brands relationship sustainability, the role of marketing ethics has become progressively important because of this uncertainty in those regions [82,83]. For increasing the trust between multiple stakeholders of the company (including customers), the superior level of ethical authority leads $[80,81]$.

Consumers and brands interact with each other continually [84]. The relational value that a company offers through ethical marketing practices determinses the intellectual and psychological procedure that enhances the interaction between customers and the brand on a sustainable basis. Correspondingly, in this study we deal with a proximity point between the ethical marketing practice and customer value-brand relationship sustainability because consumers estimate the brand and builds the relationship sustainability through some processes in which experience and interaction with the brands occur. Extended marketing mix often serves as the first contact impression through which customers know a brand and come in terms with it $[11,16]$. Consumers observe the ethical marketing practices because 
it is the most visible in a brand's manifold schemes and play important role in shaping consumer perceptions towards a brand [85-88].

Prior studies reveal that ethical problems in marketing have involved issues pertaining to product safety and quality, price fixing, deceptive promotions, illegal product placement, child labor and unfair person treatment, misleading information provided through fake physical evidence and packaging $[7,11,12,63]$. Such ethical issues revolving around fairness and human resource management affect subjective evaluations of product, and relationship value of customers [11]. Fraudulent prices are main cause of misleading the consumer's basic features to purchase, so that is why to improve the relationship between brands and consumers, right prices are needed to be set in the marketplace. Information about product should be truthful to maintain the relationship with customer because negative effects of displays could lead to unreasonable decisions by consumers $[11,37,40]$. It is suggested that ethical marketing practices related to the marketing mix elements could lead to favorable decisions by consumers which may further derive positive outcomes for the company/brand. Ethical marketing practices results in a more socially responsible and sensitive business community which eventually has the potential (in both the short and long run) to benefit the society as a whole [55,71]. Building upon these arguments, it is suggested that positive relationship occurs through a company's/brand's ethical marketing practice and their customer value-brand relationship sustainability. Therefore, we hypothesize the following:

Hypothesis 1a (H1a). Product-associated ethics shows a positive effect on customer value-brand relationship sustainability.

Hypothesis $\mathbf{1 b}(\mathbf{H} 1 \mathbf{b})$. Price-associated ethics shows a positive effect on customer value-brand relationship sustainability.

Hypothesis 1c (H1c). Place-associated ethics shows a positive effect on customer value-brand relationship sustainability.

Hypothesis 1d (H1d). Promotion-associated ethics shows a positive effect on customer valuebrand relationship sustainability.

Hypothesis 1e (H1e). Person-associated ethics shows a positive effect on customer value-brand relationship sustainability.

Hypothesis 1f (H1f). Physical evidence-associated ethics shows a positive effect on customer value-brand relationship sustainability.

Hypothesis 1g (H1g). Packaging-associated ethics shows a positive effect on customer value-brand relationship sustainability.

Value-adding product sustainability should persuade customer's wishes and demands in which safety of the product, well-being levels and habitats take place. The brands that convey ethical values with responsible behavior are the brands which are surrounded by high quality products and are chosen by the customer. Regarding the idea of product sustainability, this is referred to as the personalized sustainability that customers expect in the product. The brand that organizes the responsible actions for marketing in their products and services, receive warm respect and trust from their customers as well as from their shareholders [89-91]. Companies can achieve sustained benefits and trust from their customers only when their deals and agreements are based on the ethical marketing practices with their interested parties. As an outcome, customers prefer brands that are perceived to deliver ethical values and behave responsibly [89]. Based on these arguments, we suggest a positive association between a brand's ethical marketing practices with their value adding product sustainability. So, we propose the following hypotheses: 
Hypothesis 2a (H2a). Product-associated ethics shows a apositive effect on value adding product sustainability.

Hypothesis $\mathbf{2 b} \mathbf{( H 2 b ) . ~ P r i c e - a s s o c i a t e d ~ e t h i c s ~ s h o w s ~ a ~ p o s i t i v e ~ e f f e c t ~ o n ~ v a l u e ~ a d d i n g ~ p r o d u c t ~}$ sustainability.

Hypothesis 2c (H2c). Place-associated ethics shows a positive effect on value adding product sustainability.

Hypothesis 2d (H2d). Promotion-associated ethics shows a positive effect on value adding product sustainability.

Hypothesis 2e (H2e). Person-associated ethics shows a positive effect on value adding product sustainability.

Hypothesis $2 \mathbf{f}$ (H2f). Physical-associated ethics shows a positive effect on value adding product sustainability.

Hypothesis $2 \mathbf{g}$ (H2g). Packaging-associated ethics shows a positive effect on value adding product sustainability.

Customers always observe the brand's marketing strategies because it is one of the most perceptible fields [92-94]. Moreover, customers nudge the brand by applying mutual and emotional standards to activities, companies and stories when they chose a brand. Later on, a customer value-brand relationship builds up. Customers mostly evaluate the brand and prefers based on their experiences rather than the particular characteristics of the product. Brand loyalty also has a major role in the establishment of the brand's asset. Previous studies show that the brand loyalty and sustainability improve focusing with the B2C connection perfectly $[67,79]$. Maintaining the high quality of customer-brand relationship is a major aim of branding because relationship between customer and brand provides a sustainable competitive advantage to the companies.

Previous studies reveal that customers are always satisfied with the positive effects of product quality $[11,38]$. Also, the value of the product is intimately significant to the customer's contentment and trust because product's value can be seen as the dissimilarity between general and unexplored standards. When customers build a relationship with the brand due to its favorable brand experience and the sustained product value, it drives customers to develop loyalty intentions and stay with the brand for a longer period of time $[2,54,60]$. Therefore, value-brand relationship sustainability and value adding product sustainability play a dominant role on brand loyalty [89]. Hence, we propose the following hypotheses:

Hypothesis 3 (H3). Customer value-brand relationship sustainability have a positive effect on brand loyalty.

Hypothesis 4 (H4). Value adding product sustainability has a positive effect on brand loyalty.

Based on the above hypotheses, we developed our research model as shown in Figure 1 below. 


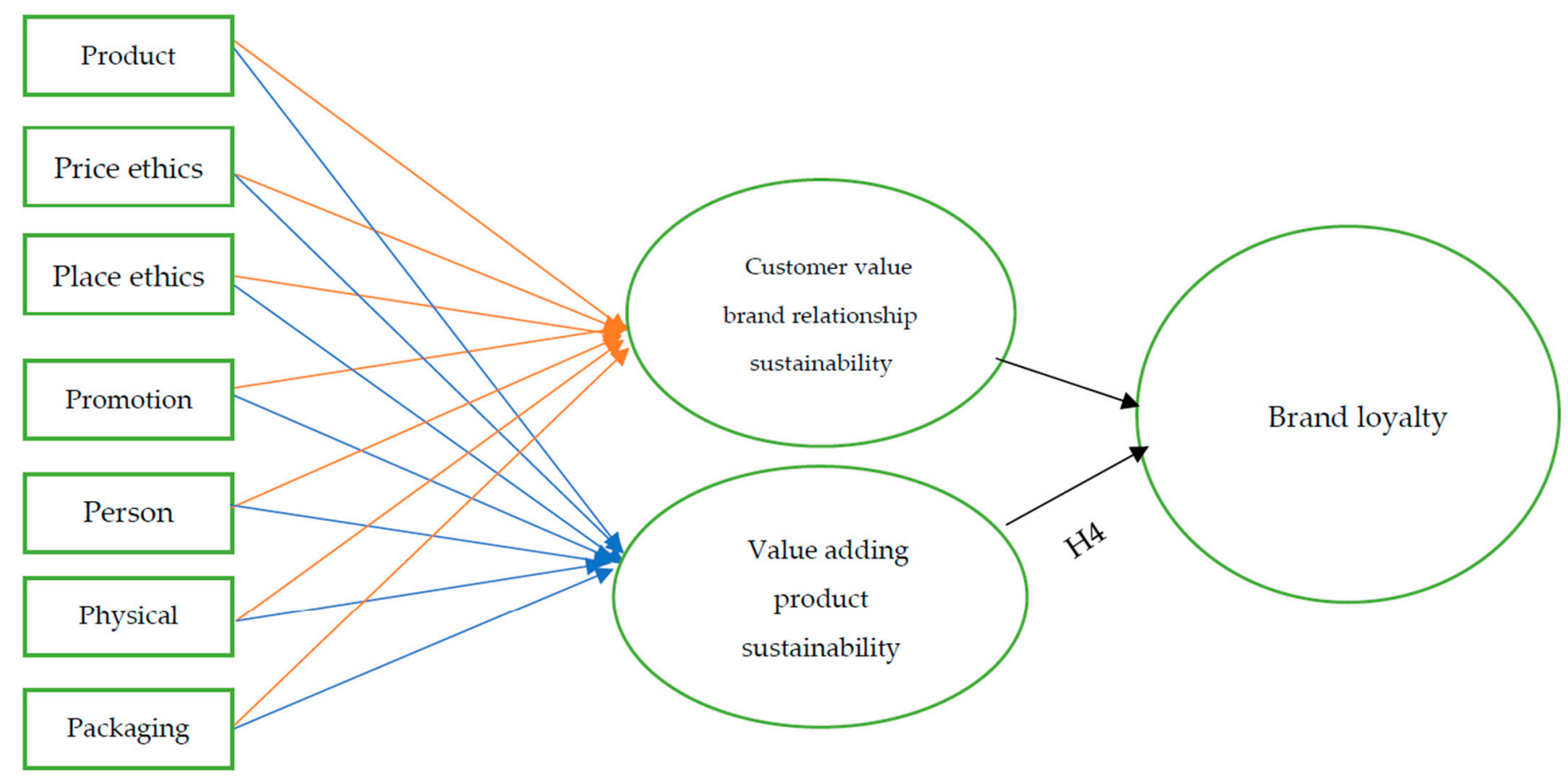

Figure 1. Proposed conceptual model.

\section{Methodology}

\subsection{Questionnaire Development and Data Collection}

The questionnaire in this study was based on independent and dependent variables. We use a non-probability snowball sampling technique. We use this technique for two reasons. First, we did not know the exact size of the population at the start of sampling. Secondly, we expected to have more respondents once we contacted any respondent. We collected 1500 participants from Islamabad - the capital city of Pakistan-who answered the questions. These participants were contacted and asked to participate in the survey by telephone calls. The participants in this survey were any brand's customers who have an understanding of the brand's ethical practices and had involvement with their outcomes more than once. After researchers and professors checked whether there is any conceptual errors or limitations in our questionnaire, we distributed our survey. The questionnaire consisted of two parts; the first part comprised the demographic questions and the second part was about the ethical marketing practices and other constructs under consideration.

The demographic profile of the participants in which their gender, age, education and household income is shown is presented in Table 1. 
Table 1. The demographic profile.

\begin{tabular}{|c|c|c|c|c|c|}
\hline & & Frequency & Percent & Valid Percent & Cumulative Percent \\
\hline \multicolumn{6}{|l|}{ Gender } \\
\hline \multirow{3}{*}{ Valid } & Male & 762 & 50.8 & 50.8 & 50.8 \\
\hline & Female & 738 & 49.2 & 49.2 & 100.0 \\
\hline & Total & 1500 & 100.0 & 100.0 & \\
\hline \multicolumn{6}{|l|}{ Age } \\
\hline \multirow{5}{*}{ Valid } & 20-29 years & 332 & 22.1 & 22.1 & 22.1 \\
\hline & 30-39 years & 461 & 30.7 & 30.7 & 52.9 \\
\hline & $40-49$ years & 442 & 29.5 & 29.5 & 82.3 \\
\hline & 50 or above & 265 & 17.7 & 17.7 & 100.0 \\
\hline & Total & 1500 & 100.0 & 100.0 & \\
\hline \multicolumn{6}{|c|}{ Education } \\
\hline \multirow{4}{*}{ Valid } & school & 418 & 27.9 & 27.9 & 27.9 \\
\hline & college & 673 & 44.9 & 44.9 & 72.7 \\
\hline & university & 409 & 27.3 & 27.3 & 100.0 \\
\hline & Total & 1500 & 100.0 & 100.0 & \\
\hline \multicolumn{6}{|c|}{ Household income } \\
\hline \multirow{5}{*}{ Valid } & up to 30,000 & 273 & 18.2 & 18.2 & 18.2 \\
\hline & $30,000-39,000$ & 444 & 29.6 & 29.6 & 47.8 \\
\hline & $40,000-49,000$ & 485 & 32.3 & 32.3 & 80.1 \\
\hline & above 50,000 & 298 & 19.9 & 19.9 & 100.0 \\
\hline & Total & 1500 & 100.0 & 100.0 & \\
\hline
\end{tabular}

\subsection{Research Instrument}

This study borrowed items from previously developed scales (for example, [11,31]) and made minor modifications to fit to the context. Ethical marketing practices are a base in this study which is set up on the righteous and behavioral standards in expressed marketing practices in the marketplaces [94,95]. In this study, the marketing mix strategy from ethical perspectives, is categorized as product-ethics, price-ethics, place-ethics, promotion-ethics, person-ethics, physical-ethics, and packaging-ethics. Questions pertaining to marketing mix elements were based around product-related ethics such as product's package, branding, and warranty of the product (e.g., the sample item is whether the company/brand offers a warranty to cover any faults). Price-related ethics comprises the pricing policy which shows if illegal prices or false prices are being used (the sample item includes if the company/brand refrains from using predatory pricing). Place-related ethics comprises the sales strategy, extent of collaboration and the transactions degree with sample item reading as "the company/brand refrains from controlling transactions by abusing its status". Promotion-related ethics based on the advertising companies with legal notices or with the leading and non-deceptive aspects (e.g., the company/brand refrains from providing false and exaggerated advertisements). Person-related ethics promotes the righteous principles that control the person's behavior and their activities (e.g., the employees of the company/brand treat its customers well). Physical-related ethics refers to the physical ambiance and workplace-related decor that promotes the service experience as well as human rights (e.g., the company/brand offers a great physical presence and environment). Packaging-related ethics is a role of company's branding and marketing policies in the message sent by company through packaging (e.g., the company/brand uses environmentally friendly materials for packaging its products and refrains from making fake promises through its packaging). There were a total of 25 items related to ethical marketing mix elements with five questions on product ethics, four questions on price ethics, four questions on place ethics, three questions on promotion ethics, three questions on person ethics, three questions on physics ethics, and three questions on packaging ethics $[92,93,96,97]$. 
We measured customer value-brand relationship sustainability with 12 questions with sample items like: "I really like to talk about the company/brand with others" [58,63,64]. Value-adding product sustainability defines the perception of the customer regarding products and its overall supremacy and leadership, which was measured using four questions, with a sample item reading as "this company's/brand's product has a unique design" [93]. Brand loyalty was measured with five questions (e.g., I am loyal to this company/brand). We used 5-point Likert-scales range from $1=$ strongly disagree to $5=$ strongly agree to measure the various constructs of this study.

\section{Data Analysis}

\subsection{Measurement Model}

In our study we used the SPSS software version 22nd IBM for all the analysis. We tested the hypotheses, the goodness of fit test and also verified the exploratory factor analysis of the proposed measurement model. We also examined the relationship between each construct employing structure equation modeling. First, we performed an exploratory factor analysis (EFA) which showed the validity and reliability of the ethical marketing constructs. Cronbach's alpha was used for this purpose because it is the most commonly used method when researchers have multiple Likert questions in a questionnaire. Cronbach's alpha determines the covariance between constructs [98], the relationship should be greater the 0.7 because it shows that the relationship is sufficiently reliable. Tables 2 and 3 below show the results.

Table 2. Results of consistency on the construct.

\begin{tabular}{ccc}
\hline Constructs & Items & Cronbach's Alpha \\
\hline Product ethics & 5 & 0.751 \\
Price ethics & 4 & 0.769 \\
Place ethics & 4 & 0.810 \\
Promotion ethics & 3 & 0.799 \\
Person ethics & 3 & 0.902 \\
Physical ethics & 3 & 0.658 \\
Packaging ethics & 3 & 0.973 \\
CVBRS & 12 & 0.836 \\
VAPS & 4 & 0.817 \\
BL & 5 & 0.796 \\
\hline
\end{tabular}

Note: CVBRS = Customer value brand relationship sustainability, VAPS = Value adding product sustainability, $\mathrm{BL}=$ Brand loyalty and sustainability.

Table 3. Discriminant Validity.

\begin{tabular}{|c|c|c|c|c|c|c|c|c|c|c|}
\hline & PRODUCT & PLACE & PROMOTION & PERSON & PRICE & PHYSICAL & PACKAGING & CVBRS & VAPS & BL \\
\hline PRODUCT & 1.000 & 0.026 & -0.027 & 0.018 & 0.001 & -0.013 & -0.071 & 0.051 & -0.018 & -0.016 \\
\hline PLACE & 0.026 & 1.000 & 0.010 & 0.018 & 0.003 & -0.033 & -0.027 & -0.003 & -0.040 & 0.004 \\
\hline PROMOTION & $\begin{array}{l}0.020 \\
-0.027\end{array}$ & 0.010 & 1.000 & 0.024 & -0.038 & -0.025 & -0.018 & 0.030 & 0.019 & $\begin{array}{l}0.004 \\
-0.018\end{array}$ \\
\hline PERSON & 0.018 & 0.018 & 0.024 & 1.000 & 0.012 & -0.049 & 0.013 & -0.003 & -0.024 & -0.041 \\
\hline PRICE & 0.001 & 0.003 & -0.038 & 0.012 & 1.000 & 0.024 & -0.056 & -0.015 & 0.048 & 0.010 \\
\hline PHYSICAL & -0.013 & -0.033 & -0.025 & -0.049 & 0.024 & 1.000 & -0.014 & 0.011 & 0.045 & 0.567 \\
\hline PACKAGING & -0.071 & -0.027 & -0.018 & 0.013 & -0.056 & -0.014 & 1.000 & -0.017 & -0.005 & 0.019 \\
\hline CVBRS & 0.051 & -0.003 & 0.030 & -0.003 & -0.015 & 0.011 & -0.017 & 1.000 & 0.031 & 0.017 \\
\hline VAPS & -0.018 & -0.040 & 0.019 & -0.024 & 0.048 & 0.045 & -0.005 & 0.031 & 1.000 & 0.069 \\
\hline $\mathrm{BL}$ & -0.016 & 0.004 & -0.018 & -0.041 & 0.010 & 0.567 & 0.019 & 0.017 & 0.069 & 1.000 \\
\hline
\end{tabular}

The Cronbach's alpha results show that all the constructs are reliable, which means there is a good probability that the constructs will perform in a defined environment without failure. The correlation coefficients are between 0.567 and -0.071 in the table of discriminant validity. The systematic assessment of discriminant validity shows that these constructs are not highly correlated to each other. As the correlation of constructs are between -0.071 and 0.567 it means there is a negative relationship between each construct with other construct, although the correlation of any construct with itself is 1.000, which shows that the data used in this study is valid and can be used for further analysis. 
In Table 2, the Cronbach's alpha values of all constructs are greater than 0.7 which clearly shows that the reliability is sufficient. We also performed principal component factor analysis which is used to diminish the dimensionality of the constructs, it is used to simplify the data like reducing the number of variables. We performed principal factor analysis with varimax rotation on the constructs, where 0.50 was taken as the minimal cutoff value. The items could be deleted from the further analysis because of the cross loading. Results of factor loadings of dependent and independent constructs are shown in the Tables 4-7.

Table 4. Independent variables factor analysis.

\begin{tabular}{|c|c|c|}
\hline Constructs & Items & Factor Loadings \\
\hline \multirow{6}{*}{ Product ethics } & PROD1 & 0.695 \\
\hline & PROD2 & 0.701 \\
\hline & PROD3 & 0.683 \\
\hline & PROD4 & 0.662 \\
\hline & PROD5 & 0.709 \\
\hline & PRICE1 & 0.882 \\
\hline \multirow[t]{4}{*}{ Price ethics } & PRICE2 & 0.796 \\
\hline & PRICE3 & 0.763 \\
\hline & PRICE4 & 0.851 \\
\hline & PLACE1 & 0.765 \\
\hline \multirow[t]{4}{*}{ Place ethics } & PLACE2 & 0.721 \\
\hline & PLACE3 & 0.893 \\
\hline & PLACE4 & 0.812 \\
\hline & PROM1 & 0.699 \\
\hline \multirow[t]{3}{*}{ Promotion ethics } & PROM2 & 0.701 \\
\hline & PROM3 & 0.687 \\
\hline & PER1 & 0.851 \\
\hline \multirow[t]{3}{*}{ Person ethics } & PER2 & 0.799 \\
\hline & PER3 & 0.837 \\
\hline & PHYS1 & 0.712 \\
\hline \multirow[t]{3}{*}{ Physical ethics } & PHYS2 & 0.735 \\
\hline & PHYS3 & 0.802 \\
\hline & PCKG1 & 0.871 \\
\hline \multirow[t]{2}{*}{ Packaging ethics } & PCKG2 & 0.865 \\
\hline & PCKG3 & 0.797 \\
\hline
\end{tabular}

Tables 6 and 7 show that the eigenvalues of each construct are higher than 1.00, which shows that the data which is selected in this study has no common method bias.

\subsection{Structural Model}

We test the hypotheses between constructs by using SEM [99], to test the casual relationship between each construct we made the hypothesis path casually to estimate what kind of relationship is present in these constructs, the results are presented in Table 8 below: 
Table 5. Dependent variables factor analysis.

\begin{tabular}{ccc}
\hline Constructs & Items & Factor Loadings \\
\hline & CVBRS1 & 0.758 \\
& CVBRS2 & 0.893 \\
CVBRS3 & 0.776 \\
& CVBRS4 & 0.852 \\
& CVBRS5 & 0.763 \\
& CVBRS6 & 0.892 \\
& CVBRS7 & 0.781 \\
& CVBRS8 & 0.741 \\
& CVBRS9 & 0.861 \\
& CVBRS10 & 0.771 \\
& CVBRS11 & 0.773 \\
& CVBRS12 & 0.796 \\
\hline \multirow{2}{*}{ VAPS } & VAPS1 & 0.821 \\
& VAPS2 & 0.854 \\
& VAPS3 & 0.743 \\
& VAPS4 & 0.861 \\
\hline
\end{tabular}

Table 6. Eigenvalues in factor loadings (independent variables): total variance explained.

\begin{tabular}{cccc}
\hline \multirow{2}{*}{ Component } & \multicolumn{3}{c}{ Initial Eigenvalues } \\
\cline { 2 - 4 } & Total & \% of Variance & Cumulative \% \\
\hline Product & 7.105 & 15.785 & 15.785 \\
Price & 6.092 & 15.597 & 31.382 \\
Place & 6.007 & 14.384 & 45.765 \\
Promotion & 4.997 & 14.246 & 60.011 \\
Person & 4.975 & 13.930 & 73.941 \\
Physical & 3.942 & 13.451 & 87.391 \\
Packaging & 2.883 & 12.609 & 100.000 \\
\hline
\end{tabular}

Note: Extraction Method: Principal Component Analysis.

Table 7. Eigenvalues in factor loadings (dependent variables): total variance explained.

\begin{tabular}{cccc}
\hline \multirow{2}{*}{ Component } & \multicolumn{3}{c}{ Initial Eigenvalues } \\
\cline { 2 - 4 } & Total & \% of Variance & Cumulative \% \\
\hline CVBRS & 6.084 & 36.126 & 36.126 \\
VAPS & 2.987 & 32.908 & 69.034 \\
BL & 2.929 & 30.966 & 100.000 \\
\hline
\end{tabular}

Note: Extraction Method: Principal Component Analysis. 
Table 8. Hypothesis test results.

\begin{tabular}{ccc}
\hline Hypothesis & Sig. Values & Results \\
\hline H1a (PROD-CVBRS) & 0.251 & Significant \\
H1b (PRICE-CVBRS) & 0.135 & Significant \\
H1c (PLACE-CVBRS) & 0.119 & Significant \\
H1d (PROM-CVBRS) & 0.047 & Not significant \\
H1e (PER-CVBRS) & 0.310 & Significant \\
H1f (PHYS-CVBRS) & 0.227 & Significant \\
H1g (PCKG-CVBRS) & 0.094 & Not significant \\
\hline H2a (PROD-VAPS) & 0.310 & Significant \\
H2b (PRICE-VAPS) & 0.026 & Not significant \\
H2c (PLACE-VAPS) & 0.222 & Significant \\
H2d (PROM-VAPS) & 0.300 & Significant \\
H2e (PER-VAPS) & 0.119 & Significant \\
H2f (PHYS-VAPS) & 0.273 & Significant \\
H2g (PCKG-VAPS) & 0.303 & Significant \\
\hline H3 (CVBRS-BL) & 0.481 & Significant \\
\hline H4 (VAPS-BL) & 0.396 &
\end{tabular}

\section{Discussion}

This study aimed at investigating the elements of marketing mix and brand relationship from an ethical marketing perspective. To empirically validate our proposed conceptual model, sixteen hypotheses were tested in the current study, of which thirteen revealed a positively significant relationship and were supported. The remaining three hypotheses were not supported by our results. Hypotheses H1a, H1b, H1c, H1e, and H1f specifying the areas of ethical marketing practices i.e., product, price, place, person and physical ethics have a positively significant effect on the customer value-brand relationship sustainability. However, H1d was not supported, revealing that promotion ethics has no significant effect on customer value-brand relationship sustainability. $(\gamma=0.047<p=0.05)$. Similarly, H1g also revealed a non-significant effect of packaging ethics on customer valuebrand relationship sustainability $(\gamma=0.094>p=0.05)$. In a similar vein, $\mathrm{H} 2 \mathrm{a}, \mathrm{H} 2 \mathrm{c}, \mathrm{H} 2 \mathrm{~d}$, $\mathrm{H} 2 \mathrm{e}, \mathrm{H} 2 \mathrm{f}$ and $\mathrm{H} 2 \mathrm{~g}$ identify that the ethical marketing practices in terms of product, place, promotion, person, physical evidence, and packaging are significantly affecting the value adding product sustainability, whereas $\mathrm{H} 2 \mathrm{~b}$ shows that price ethics has no significant effect on value adding product sustainability $(\gamma=0.026<p=0.05)$. Lastly, both H3 identifying the positive relationship between customer value-brand relationship sustainability and brand loyalty and $\mathrm{H} 4$ examining the effect of value adding product sustainability on brand loyalty were supported by the results.

The current study studies the role of ethical marketing practices to build positive relationships between customers and brands. Hypotheses testing shows the relationship between these variables and the findings show that, except for promotion ethics and packaging ethics, all other ethical marketing practices have a positive effect on customer value-brand relationship sustainability. Similarly, except for price ethics, all other ethical practices have a significantly positive effect on value-adding product sustainability, which is in sync with some prior studies in different geographic and industrial contexts (e.g., [11,100-102]). Our results suggested that product, price, place, person, and physical ethics are very important for customer value-brand relationship sustainability. This shows that products should be free of harm for users and environment. This concept would increase the value to the customer. In the same manner, the ethical place is also equally crucial as a place should not harm any inhabitant in the environment. Moreover, physical and person ethics are essential to customer value-brand relationship sustainability. Nevertheless, ethical price is also essential for the customer, which can be achieved by avoiding any fraudulent or illegal practices in pricing. Furthermore, our findings suggest that the ethical marketing practices regarding product, place, promotion, person, physical evidence, and 
packaging significantly affect the value-adding product sustainability. Our results reveal that product ethics significantly affect customer value-brand relationship sustainability and value adding product sustainability, suggesting that customers are inclined to purchase the product with the highest level of product safety and quality. Also, the product's packaging and branding affect customer's trust and satisfaction, which is why it is important to evaluate the product ethics regarding customer value-brand relationship and sustainability and value-adding product sustainability. Besides, value-adding sustainability is established when the company hones authentic communication under legal legislation and leading abilities, i.e., truthfulness and accurate information about the product, which exhibits trustworthiness in the brand. Packaging ethics has an insignificant effect on customer value-brand relationship sustainability as customers want to see beyond the message the company is sending through their packages. However, packaging ethics have a positive effect on value-adding product sustainability, so it is worthwhile for companies to build up a strong relationship with customers. If a company enhances its relationship quality through product, price, place, promotion, person, physical and packaging ethics, we expect more effectiveness on brand loyalty through exciting relationships with customers.

\subsection{Implications}

The academic literature on B2C transactions concludes that there is some evidence of positive effects of traditional marketing practices (in the form of product, price, place and promotion) on brand loyalty. However, our contribution to the literature is first of its kind because an improved model for analysis has been used. The focus is on studying the relationship between ethical marketing practices of an extended marketing mix elements and consumer-brand relationship and brand loyalty, which is common in B2C transactions. Our additional theoretical contribution lies in the fact that most of the studies about ethical marketing practices have been conducted in the Western countries, leaving a huge gap in the literature, which this study fills by conducting in a developing economy context of Pakistan. Besides, this study proposes and empirically validates a novel model from a sustainable marketing approach incorporating the role of relationship marketing, which further reflects its theoretical contributions. Lastly, this study further contributes by employing different theories (e.g., ethical marketing theory, relationship marketing theory) to the context of marketing mix elements and brand loyalty, thereby further generalizing the use of these theories.

As for the practical implications are concerned, managers should consider the ethical marketing practices to ensure sustainable success through relationship building and by facilitating long-term brand loyalty. Companies need to focus on improving product parameters like quality, safety, warranties, and eco-friendliness. Companies also need to take price regulations seriously in building sustained loyalty towards the brand. If companies offer a suitable price, they can attract more customers to tighten the relation between them. Customers most probably need the products with more viable prices. If a supplier does not pay heed to the customers with feasible price-concerned morals, the cons of brand truthfulness can be seen at the end. Furthermore, given that promotion-related ethics signifies the vital role in bringing value adding product sustainability. Therefore, firms need to evaluate the promotion related ethics to maximize the trust-based activities to cement the associations with firms. The summarized implication here is that companies/brands can sustain even during the fierce market competition if they establish an ethical culture which gives due preference to trust-based transactions, thereby strengthening customer-firm relationships. Our findings are expected to provide valuable implications to companies so that they support an effective marketing strategy from an ethical perspective.

\subsection{Limitations and Suggestions}

Regardless of its contribution and implications, this study has several limitations, Firstly, while examining the interplay of marketing ethics and brand loyalty, we didn't consider B2B transactions. Moreover, our proposed relationships may vary across industrial 
contexts types, therefore, future studies may further validate our model across study settings. Moreover, future analysis should consider the more ethical practices from the point of government ethics, culture ethics, individual ethics, and religiosity to present further insights of the domain. Some circumstantial and individual factors (e.g., personality type) may act as potential moderators, which future studies can also consider. A longitudinal study may also be conducted to gauge loyalty formation over a period of time.

Author Contributions: Conceptualization, M.T. and A.-R.A.; methodology, M.T.; software, A.-R.A.; validation, M.T., A.-R.A. and H.M.; formal analysis, A.-R.A.; investigation, M.T.; resources, M.T.; data curation, M.T.; writing —original draft preparation, M.T. and A.-R.A.; writing-review and editing, H.M. and I.U.H.; visualization, M.T. and I.U.H.; supervision, M.T. All authors have read and agreed to the published version of the manuscript.

Funding: This research received no external funding.

Institutional Review Board Statement: Not applicable.

Informed Consent Statement: Not applicable.

Data Availability Statement: Not applicable.

Acknowledgments: All authors of this article would like to thank the Prince Sultan University for their financial and academic support and publish in "Sustainability".

Conflicts of Interest: The authors declare no conflict of interest.

\section{References}

1. Islam, J.U.; Rahman, Z. The impact of online brand community characteristics on customer engagement: An application of Stimulus-Organism-Response paradigm. Telemat. Inform. 2017, 34, 96-109. [CrossRef]

2. Islam, J.U.; Shahid, S.; Rasool, A.; Rahman, Z.; Khan, I.; Rather, R.A. Impact of website attributes on customer engagement in banking: A solicitation of stimulus-organism-response theory. Int. J. Bank Mark. 2020, 38, 1279-1303. [CrossRef]

3. Kaur, H.; Paruthi, M.; Islam, J.; Hollebeek, L.D. The role of brand community identification and reward on consumer brand engagement and brand loyalty in virtual brand communities. Telemat. Inform. 2020, 46, 101321. [CrossRef]

4. Andreassen, T.W.; Lindestad, B. Customer loyalty and complex services: The impact of corporate image on quality, customer satisfaction and loyalty for customers with varying degrees of service expertise. Int. J. Serv. Ind. Manag. 1998, 9, 7-23. [CrossRef]

5. Dowling, G.R.; Uncles, M. Do customer loyalty programs really work? Sloan Manag. Rev. 1997, 38, 71-82.

6. Utami, S. The Influence of Customers' Trust on Customer Loyalty. Int. J. Econ. Commer. Manag. 2015, 3, $638-653$.

7. Alrubaiee, L.; Al-Nazer, N. Investigate the impact of relationship marketing orientation on customer loyalty: The customer's perspective. Int. J. Mark. Stud. 2010, 2, 155. [CrossRef]

8. Kumar, V.; Sharma, A.; Shah, R.; Rajan, B. Establishing profitable customer loyalty for multinational companies in the emerging economies: A conceptual framework. J. Int. Mark. 2013, 21, 57-80. [CrossRef]

9. Jiménez-Zarco, A.I.; Rospigliosi, A.; Martínez-Ruiz, M.P.; Izquierdo-Yusta, A. Marketing 4.0: Enhancing consumer-brand engagement through big data analysis. In Web Services: Concepts, Methodologies, Tools, and Applications; IGI Global: Hershey, PA, USA, 2019; pp. 2172-2195.

10. Tanveer, M. Analytical approach on small and medium Pakistani Business based on E-Commerce Ethics with effect on customer repurchase objectives and loyalty. J. Leg. Ethical Regul. Issues 2021, 24, 1-10.

11. Kotler, P.; Lee, N. Best of breed: When it comes to gaining a market edge while supporting a social cause, "corporate social marketing" leads the pack. Soc. Mark. Q. 2005, 11, 91-103. [CrossRef]

12. Brunk, K.H. Exploring origins of ethical company/brand perceptions-A consumer perspective of corporate ethics. J. Bus. Res. 2010, 63, 255-262. [CrossRef]

13. David, F.R.; David, F.R.; David, M.E. Strategic Management: Concepts and Cases: A Competitive Advantage Approach; Pearson: Upper Saddle River, NJ, USA, 2013.

14. Kaplan, R.S.; Norton, D.P. The Execution Premium: Linking Strategy to Operations for Competitive Advantage; Harvard Business Press: Boston, MA, USA, 2008.

15. Weeden, C. Ethical tourism: An opportunity for competitive advantage? J. Vacat. Mark. 2002, 8, 141-153. [CrossRef]

16. Berger, L.A.; Berger, D.R. The Talent Management Handbook: Creating a Sustainable Competitive Advantage by Selecting, Developing, and Promoting the Best People; McGraw-Hill: New York, NY, USA, 2011.

17. Papadimitri, P.; Pasiouras, F.; Tasiou, M. Do national differences in social capital and corporate ethical behaviour perceptions influence the use of collateral? Cross-country evidence. J. Bus. Ethics 2020. [CrossRef]

18. Lee, J.Y.; Jin, C.H. The role of ethical marketing issues in consumer-brand relationship. Sustainability 2019, 11, 6536. [CrossRef] 
19. Vallaster, C.; Kraus, S.; Lindahl, J.M.M.; Nielsen, A. Ethics and entrepreneurship: A bibliometric study and literature review. J. Bus. Res. 2019, 99, 226-237. [CrossRef]

20. Rekker, S.A.; Benson, K.L.; Faff, R.W. Corporate social responsibility and CEO compensation revisited: Do disaggregation, market stress, gender matter? J. Econ. Bus. 2014, 72, 84-103. [CrossRef]

21. Sahin, A.; Zehir, C.; Kitapçı, H. The effects of brand experiences, trust and satisfaction on building brand loyalty; an empirical research on global brands. Proc. Soc. Behav. Sci. 2011, 24, 1288-1301. [CrossRef]

22. Tanveer, M.; Hassan, S.; Bhaumik, A. Academic Policy Regarding Sustainability and Artificial Intelligence (AI). Sustainability 2020, 12, 9435. [CrossRef]

23. Kuo, Y.F.; Feng, L.H. Relationships among community interaction characteristics, perceived benefits, community commitment, and oppositional brand loyalty in online brand communities. Int. J. Inf. Manag. 2013, 33, 948-962. [CrossRef]

24. Nandan, S. An exploration of the brand identity-brand image linkage: A communications perspective. J. Brand Manag. 2005, 12, 264-278. [CrossRef]

25. Cuomo, M.T.; Foroudi, P.; Tortora, D.; Hussain, S.; Melewar, T.C. Celebrity Endorsement and the Attitude Towards Luxury Brands for Sustainable Consumption. Sustainability 2019, 11, 6791. [CrossRef]

26. Alwi, S.F.; Ali, S.M.; Nguyen, B. The importance of ethics in branding: Mediating effects of ethical branding on company reputation and brand loyalty. Bus. Ethics Q. 2017, 27, 393-422. [CrossRef]

27. Hur, W.M.; Ahn, K.H.; Kim, M. Building brand loyalty through managing brand community commitment. Manag. Decis. 2011, 49, 1194-1213. [CrossRef]

28. So, K.K.F.; King, C.; Sparks, B.A.; Wang, Y. The influence of customer brand identification on hotel brand evaluation and loyalty development. Int. J. Hosp. Manag. 2013, 34, 31-41. [CrossRef]

29. Haryanto, J.O.; Moutinho, L.; Coelho, A. Is brand loyalty really present in the children's market? A comparative study from Indonesia, Portugal, and Brazil. J. Bus. Res. 2016, 69, 4020-4032. [CrossRef]

30. Hem, L.E.; Iversen, N.M. Transfer of brand equity in brand extensions: The importance of brand loyalty. ACR North American Advances. In NA-Advances in Consumer Research; Keller, P.A., Rook, D.W., Valdosta, G.A., Eds.; Association for Consumer Research: Columbus, OH, USA, 2003; Volume 30, pp. 72-79.

31. Sebastianelli, R.; Tamimi, N.; Rajan, M. Perceived quality of online shopping: Does gender make a difference? J. Int. Commer. 2008, 7, 445-469. [CrossRef]

32. Thirumalai, S.; Sinha, K.K. Customer satisfaction with order fulfillment in retail supply chains: Implications of product type in electronic B2C transactions. J. Oper. Manag. 2005, 23, 291-303. [CrossRef]

33. Bostrom, N.; Roache, R. Ethical issues in human enhancement. In New Waves in Applied Ethics; Ryberg, J., Petersen, T., Wolf, C., Eds.; Palgrave Macmillan: Basingstoke, UK, 2008; pp. 120-152.

34. Tanveer, M.; Hassan, S. The role of new and creative ideas in developing industries of education, software and manufacturing in Pakistan. J. Entrep. Educ. 2020, 23, 1-10.

35. Floridi, L.; Sanders, J.W. Artificial evil and the foundation of computer ethics. Ethics Inf. Technol. 2001, 3, 55-66. [CrossRef]

36. Connolly, W.E. Beyond good and evil: The ethical sensibility of Michel Foucault. Polit. Theory 1993, 21, 365-389. [CrossRef]

37. Cooper, J.M. Reason and Emotion: Essays on Ancient Moral Psychology and Ethical Theory; Princeton University Press: Princeton, NJ, USA, 1999.

38. Resnik, D.B. What Is Ethics in Research and Why Is It Important; National Institute of Health: Stapleon, NY, USA, 2011. Available online: https: / / www.niehs.nih.gov/research/resources/bioethics/whatis/index.cfm\#: \{\{\}:text=There $\% 20$ are $\% 20$ several $\% 20$ reasons\%20why, the \%20truth\%20and\%20minimize\%20error (accessed on 12 February 2021).

39. Goulet, D. Development ethics: A new discipline. Int. J. Soc. Econ. 1997, 24, 1160-1171. [CrossRef]

40. Lund, D.B. An empirical examination of marketing professional's ethical behavior in differing situations. J. Bus. Ethics 2000, 24, 331-342. [CrossRef]

41. Kock, C. Choice is not true or false: The domain of rhetorical argumentation. Argumentation 2009, 23, 61-80. [CrossRef]

42. Bowie, N.E. Business ethics as a discipline: The search for legitimacy. In The Ruffin Series in Business Ethics; Oxford University Press: Oxford, UK, 1991.

43. Wright, C. Truth in Ethics. Ratio 1995, 8, 209-226. [CrossRef]

44. Zwingli, U. Commentary on True and False Religion; Wipf and Stock Publishers: Eugene, OR, USA, 2015.

45. Gaski, J.F. Does marketing ethics really have anything to say? A critical inventory of the literature. J. Bus. Ethics 1999, 18, 315-334.

46. Tanveer, M.; Khan, N.; Ahmad, A.R. AI Support Marketing: Understanding the Customer Journey towards the Business Development. In Proceedings of the 2021 1st International Conference on Artificial Intelligence and Data Analytics (CAIDA), Riyadh, Saudi Arabia, 6-7 April 2021; pp. 144-150. [CrossRef]

47. Pearson, R. Business ethics as communication ethics: Public relations practice and the idea of dialogue. Public Relat. Theory 1989, 27, 111-131.

48. Ferrell, O.C.; Harrison, D.E.; Ferrell, L.; Hair, J.F. Business ethics, corporate social responsibility, and brand attitudes: An exploratory study. J. Bus. Res. 2019, 95, 491-501. [CrossRef]

49. Aaleya, R.; Farooq, A.S.; Muhammad, T. Relational Dynamics between Customer Engagement, Brand Experience, and Customer Loyalty: An Empirical Investigation. J. Internet Commer. 2021. [CrossRef] 
50. Domino, M.A.; Wingreen, S.C.; Blanton, J.E. Social cognitive theory: The antecedents and effects of ethical climate fit on organizational attitudes of corporate accounting professionals-A reflection of client narcissism and fraud attitude risk. J. Bus. Ethics 2015, 131, 453-467. [CrossRef]

51. Ferrero, I.; Sison, A.J.G. A quantitative analysis of authors, schools and themes in virtue ethics articles in business ethics and management journals (1980-2011). Bus. Ethics A Eur. Rev. 2014, 23, 375-400. [CrossRef]

52. McGuire, J.B.; Sundgren, A.; Schneeweis, T. Corporate social responsibility and firm financial performance. Acad. Manag. J. 1988, 31, 854-872.

53. Dunfee, T.W.; Smith, N.C.; Ross, W.T., Jr. Social contracts and marketing ethics. J. Mark. 1999, 63, 14-32. [CrossRef]

54. Singhapakdi, A.; Vitell, S.J. Marketing ethics: Factors influencing perceptions of ethical problems and alternatives. J. Macromark. 1990, 10, 4-18. [CrossRef]

55. Saeed, M.; Ahmed, Z.U.; Mukhtar, S.M. International marketing ethics from an Islamic perspective: A value-maximization approach. J. Bus. Ethics 2001, 32, 127-142. [CrossRef]

56. Nantel, J.; Weeks, W.A. Marketing ethics: Is there more to it than the utilitarian approach? Eur. J. Mark. 1996, 30, 9-19. [CrossRef]

57. Reidenbach, R.E.; Robin, D.P.; Dawson, L. An application and extension of a multidimensional ethics scale to selected marketing practices and marketing groups. J. Acad. Mark. Sci. 1991, 19, 83-92. [CrossRef]

58. Perrea, T.; Grunert, K.G.; Krystallis, A. Consumer value perceptions of food products from emerging processing technologies: A cross-cultural exploration. Food Qual. Prefer. 2015, 39, 95-108. [CrossRef]

59. Fournier, S. Consumers and their brands: Developing relationship theory in consumer research. J. Consum. Res. 1998, 24, 343-373. [CrossRef]

60. Tanveer, M.; Karim, M.A. Higher Education Institutions and the Performance Management. Library Philosophy and Practice. 2018, p. 2183. Available online: https:/ / digitalcommons.unl.edu/libphilprac/3010/ (accessed on 20 March 2021).

61. Dudiak, J. The Intrigue of Ethics: A Reading of the Idea of Discourse in the Thought of Emmanuel Levinas; Fordham University Press: New York, NY, USA, 2001.

62. Slade, S.; Prinsloo, P. Learning analytics: Ethical issues and dilemmas. Am. Behav. Sci. 2013, 57, 1510-1529. [CrossRef]

63. Steinbock, B.; London, A.J.; Arras, J. Ethical Issues in Modern Medicine: Contemporary Readings in Bioethics; McGraw-Hill: New York, NY, USA, 2013.

64. Zimmermann, M. Ethical guidelines for investigations of experimental pain in conscious animals. Pain 1983, 16, 109-110. [CrossRef]

65. Roberts, K.; Varki, S.; Brodie, R. Measuring the quality of relationships in consumer services: An empirical study. Eur. J. Mark. 2003, 37, 169-196. [CrossRef]

66. Rogge, R.D.; Fincham, F.D.; Crasta, D.; Maniaci, M.R. Positive and negative evaluation of relationships: Development and validation of the Positive-Negative Relationship Quality (PN-RQ) scale. Psychol. Assess. 2017, 29, 1028. [CrossRef] [PubMed]

67. Athanasopoulou, P. Relationship quality: A critical literature review and research agenda. Eur. J. Mark. 2009, 43, 583-610. [CrossRef]

68. Crosby, L.A.; Evans, K.R.; Cowles, D. Relationship quality in service selling: An interpersonal influence perspective. J. Mark. 1990, 54, 68-81. [CrossRef]

69. Krishnamurthi, L.; Raj, S.P. An empirical analysis of the relationship between brand loyalty and consumer price elasticity. Mark. Sci. 1991, 10, 172-183. [CrossRef]

70. Thaichon, P.; Quach, T.N. From marketing communications to brand management: Factors influencing relationship quality and customer retention. J. Relatsh. Mark. 2015, 14, 197-219. [CrossRef]

71. Hess, J.; Story, J. Trust-based commitment: Multidimensional consumer-brand relationships. J. Consum. Mark. 2005, 22, 313-322. [CrossRef]

72. Dwivedi, A.; Johnson, L.W.; McDonald, R. Celebrity endorsements, self-brand connection and relationship quality. Int. J. Advert. 2016, 35, 486-503. [CrossRef]

73. Van der Westhuizen, L.M. Brand loyalty: Exploring self-brand connection and brand experience. J. Prod. Brand Manag. 2018, 27, 172-184. [CrossRef]

74. Thakor, M.V.; Lavack, A.M. Effect of perceived brand origin associations on consumer perceptions of quality. J. Prod. Brand Manag. 2003, 12, 393-407. [CrossRef]

75. Khan, I.; Hollebeek, L.D.; Fatma, M.; Islam, J.U.; Riivits-Arkonsuo, I. Customer experience and commitment in retailing: Does customer age matter? J. Retail. Consum. Serv. 2020, 57, 102219. [CrossRef]

76. Islam, J.U.; Rahman, Z.; Hollebeek, L.D. The role of consumer engagement in recovering online service failures: An application of service-dominant logic. In Handbook of Research on Customer Engagement; Edward Elgar Publishing: Cheltenham, UK, 2019.

77. Srinivasan, S.S.; Anderson, R.; Ponnavolu, K. Customer loyalty in e-commerce: An exploration of its antecedents and consequences. J. Retail. 2002, 78, 41-50. [CrossRef]

78. Yi, Y.; Jeon, H. Effects of loyalty programs on value perception, program loyalty, and brand loyalty. J. Acad. Mark. Sci. 2003, 31, 229-240. [CrossRef]

79. Oliver, R.L. Whence consumer loyalty? J. Mark. 1999, 63, 33-44. [CrossRef]

80. Islam, J.U.; Zaheer, A. Using Facebook brand communities to engage customers: A new perspective of relationship marketing. PEOPLE Int. J. Soc. Sci. 2016, 2, 1540-1551. [CrossRef] 
81. Islam, J.U.; Rahman, Z. Examining the effects of brand love and brand image on customer engagement: An empirical study of fashion apparel brands. J. Glob. Fash. Mark. 2016, 7, 45-59. [CrossRef]

82. Nill, A.; Schibrowsky, J.A. Research on marketing ethics: A systematic review of the literature. J. Macromark. 2007, 27, 256-273. [CrossRef]

83. Laczniak, G.R.; Murphy, P.E. The role of normative marketing ethics. J. Bus. Res. 2019, 95, 401-407. [CrossRef]

84. Hennig-Thurau, T.; Gwinner, K.P.; Walsh, G.; Gremler, D.D. Electronic word-of-mouth via consumer-opinion platforms: What motivates consumers to articulate themselves on the internet? J. Interact. Mark. 2004, 18, 38-52. [CrossRef]

85. Vitell, S.J.; Lumpkin, J.R.; Rawwas, M.Y. Consumer ethics: An investigation of the ethical beliefs of elderly consumers. J. Bus. Ethics 1991, 10, 365-375. [CrossRef]

86. Kumar, P. Ethical marketing practices viewed through consumer spectacles. Mark. Trž. 2016, 28, 29-45.

87. Johnston, J. The citizen-consumer hybrid: Ideological tensions and the case of Whole Foods Market. Theory Soc. 2008, 37, 229-270. [CrossRef]

88. Smith, N.C.; Cooper-Martin, E. Ethics and target marketing: The role of product harm and consumer vulnerability. J. Mark. 1997, 61, 1-20. [CrossRef]

89. Keller, K.L. Branding and brand equity. In Handbook of Marketing; Sage Publishers: New York, NY, USA, 2002. [CrossRef]

90. Colquitt, L.; Wesson, O.B. Improving Performance and Commitment in the Workplace; McGraw-Hill: Irwin, FL, USA, 2009.

91. Isaksson, L. Corporate Social Responsibility: A Study of Strategic Management and Performance in Swedish Firms. Ph.D. Thesis, Bond University, Robina, Australia, 2012.

92. Ching, A.T. Consumer learning and heterogeneity: Dynamics of demand for prescription drugs after patent expiration. Int. J. Ind. Organ. 2010, 28, 619-638. [CrossRef]

93. Nash, J. Exploring how social media platforms influence fashion consumer decisions in the UK retail sector. J. Fash. Mark. Manag. 2019, 23, 82-103. [CrossRef]

94. Bodet, G.; Geng, H.E.; Chanavat, N.; Wang, C. Sport brands' attraction factors and international fans. Sport Bus. Manag. 2020, 10, 47-67. [CrossRef]

95. Cambra-Fierro, J.; Hart, S.; Polo-Redondo, Y. Environmental respect: Ethics or simply business? A study in the small and medium enterprise (SME) context. J. Bus. Ethics 2008, 82, 645-656. [CrossRef]

96. Ross, W.T.; Robertson, D.C. A typology of situational factors: Impact on salesperson decision-making about ethical issues. J. Bus. Ethics 2003, 46, 213-234. [CrossRef]

97. Lewenstein, B.V. What counts as a social and ethical issue in nanotechnology? In Nanotechnology Challenges: Implications for Philosophy, Ethics and Society; World Scientific Publishing: Singapore, 2006.

98. Gliem, J.A.; Gliem, R.R. Calculating, interpreting, and reporting Cronbach's alpha reliability coefficient for Likert-type scales. In Proceedings of the Midwest Research-to-Practice Conference in Adult, Continuing, and Community Education, Columbus, OH, USA, 8-10 October 2003. Available online: https:/ / scholarworks.iupui.edu/handle/1805/344 (accessed on 26 April 2021).

99. Koufteros, X.A. Testing a model of pull production: A paradigm for manufacturing research using structural equation modeling. J. Oper. Manag. 1999, 17, 467-488. [CrossRef]

100. Luchs, M.G.; Naylor, R.W.; Irwin, J.R.; Raghunathan, R. The sustainability liability: Potential negative effects of ethicality on product preference. J. Mark. 2010, 74, 18-31. [CrossRef]

101. Yin, J.; Qian, L.; Singhapakdi, A. Sharing sustainability: How values and ethics matter in consumers' adoption of public bicycle-sharing scheme. J. Bus. Ethics 2018, 149, 313-332. [CrossRef]

102. Carmeli, A.; Brammer, S.; Gomes, E.; Tarba, S.Y. An organizational ethic of care and employee involvement in sustainability-related behaviors: A social identity perspective. J. Organ. Behav. 2017, 38, 1380-1395. [CrossRef] 